\title{
ANALISA TREN SKIN CARE NATURAL TERHADAP PREFERENSI KONSUMEN
}

\author{
Andreas Kevin'; Clarisa Kusuma²; Emiliana Hertati³; Kartika Ayu Fitriani4; Vincent Wirawan ${ }^{5}$ \\ Business Innovation; Universitas Prasetiya Mulya \\ Jl. R.A.Kartini, RT.14/RW.6, Cilandak Barat, \\ Cilandak, Kota Jakarta Selatan, Daerah Khusus Ibukota Jakarta 12430 \\ qzu4288@gmail.com¹; clarisa.kusuma@student.pmbs.ac.id²; emiliana.hertati@student.pmbs.ac.id ${ }^{3}$; \\ kartika.fitriani@student.pmbs.ac.id ${ }^{4}$; vincent.wirawan@student.pmbs.ac.id ${ }^{5}$
}

\begin{abstract}
ABSTRAK
Analisis ini bertujuan untuk menganalisa tren produk berbahan natural mempengaruhi preferensi konsumen pengguna skin care. Polusi udara yang semakin memburuk telah menimbulkan permasalahan-permasalahan kulit wajah seperti kulit kusam dan jerawat. Perubahan gaya hidup masyarakat dan meningkatnya akses informasi tentang kesehatan dan pendidikan membuat mereka mulai memperhatikan label-label yang terpasang pada produk perawatan kulit. Konsumen mulai beralih dan mempertimbangkan pentingnya bahan baku natural pada produk perawatan kulit mereka sehari-hari. Penggunaan produk-produk perawatan kulit berbahan baku natural dinilai cukup efektif dalam menyelesaikan permasalahan wajah.
\end{abstract}

Kata Kunci : perawatan wajah, natural, polusi udara, kulit kusam, jerawat.

\begin{abstract}
This research is made to analyzed the effect of natural products trend to customer preference in buying skin care product. The increasing air pollution has caused facial skin problems such as dull skin and acne. The changing of lifestyles and easiness of information access about health and education nowadays has made people more aware of labels in skin care products. People nowadays started to pay attention to ingredients in skin care products and prefer to buy one with natural ingredients for their daily use. The usage of these natural skin care products are believed to be effective in solving their facial skin problems.
\end{abstract}

Keywords : skin care, natural, pollution, dull skin, acne.

\section{PENDAHULUAN}

Sejak dahulu, dimana belum ada produk perawatan kulit di Indonesia, wanita Indonesia memiliki tradisinya sendiri untuk menjaga kecantikan kulitnya dengan memanfaatkan bahan-bahan yang dapat ditemukan dari alam seperti buah-buahan, biji-bijian, dll. Misal : masker pepaya untuk kulit lembut dan bercahaya, putih telur untuk mengencangkan kulit. Namun dengan bermunculannya banyak produk perawatan kulit, masyarakat Indonesia lebih memilih produk yang sudah siap dipakai karena tidak menghabiskan banyak waktu dibandingkan mengolahnya sendiri. 
Seiring dengan perubahan gaya hidup masyarakat yang dipengaruhi oleh kesadaran kepedulian lingkungan, tren millenial, dan meningkatnya akses informasi kesehatan dan pendidikan, banyak konsumen saat ini yang menuntut transparansi dari produk yang mereka beli. Mereka mulai mencari tahu informasi asal produk dibuat dan bahan baku membuat produk yang mereka beli. Perubahan gaya hidup masyarakat ini banyak mengubah tren industri saat ini dan mempengaruhi cara suatu organisasi beroperasi.

Pada saat ini ada istilah 'green consumer' yaitu konsumen yang memiliki kebiasaan yang ramah lingkungan dan atau yang membeli produk yang ramah lingkungan. Menurut laporan konsumsi Eropa, diperoleh hasil sebesar 10\% konsumen menyadari keberadaan label ramah lingkungan atau label hemat energi di tempat-tempat belanja. Di negara-negara barat, kesadaran atas kepedulian lingkungan dan green policy terbentuk dari kepedulian konsumen atas lingkungan, meskipun belum banyak perusahaan yang mencapai level yang sama dalam kesadaran lingkungan dibanding konsumen. Selain itu, konsumen saat ini sudah mulai memperhatikan bahan baku yang digunakan untuk suatu produk salah satunya produk skin care. Konsumen mulai teredukasi akan penggunaan bahan baku natural pada produk skin care.

Menurut laporan Organic Personal Care Product Market for Skin Care, Hair Care, Oral Care and Cosmetics 2012-2018, diprediksi akan terjadi peningkatan pasar untuk produk natural dan organik karena semakin mudah akses informasi saat ini yang dipengaruhi banyaknya beauty blogger dan akun media sosial yang memberikan banyak edukasi benefit produk natural. Selain itu semakin banyak bukti bahwa beberapa bahan kimia tertentu dapat mempengaruhi masalah kesehatan, dari masalah kesuburan, keguguran, sampai dengan kanker.

Selain itu, polusi udara di Indonesia khususnya daerah perkotaan yang semakin memburuk membuat permasalahan kulit wajah di Indonesia meningkat. Menurut CNN Indonesia (25/7/2018), berdasarkan data organisasi pemantau kualitas udara Amerika Serikat, Air Visual, pada tanggal 24 Juli 2018 Jakarta memegang gelar kota dengan polusi udara tertinggi di dunia dengan Indeks Kualitas Udara (AQI) 
mencapai angka 182. Angka ini terus berfluktuasi, namun hingga saat ini Jakarta masih termasuk dalam top five kota dengan kualitas udara terburuk di dunia.

Cosmetic Science, dikutip dari Fung Global Retail \& Technology, menemukan adanya hubungan antara polusi atmosfer dan penuaan kulit dini, bahwa udara yang tercemar dapat mempengaruhi kualitas kulit dalam hal peningkatan sebum yang dapat menyebabkan wajah menjadi kelebihan minyak, menurunkan vitamin E yang berfungsi untuk meningkatkan produksi kolagen untuk menjaga elastisitas kulit wajah, dan peningkatan asam laktat, di mana asam laktat berfungsi untuk membantu pembentukan sel kulit baru dengan mengangkat sel kulit mati.

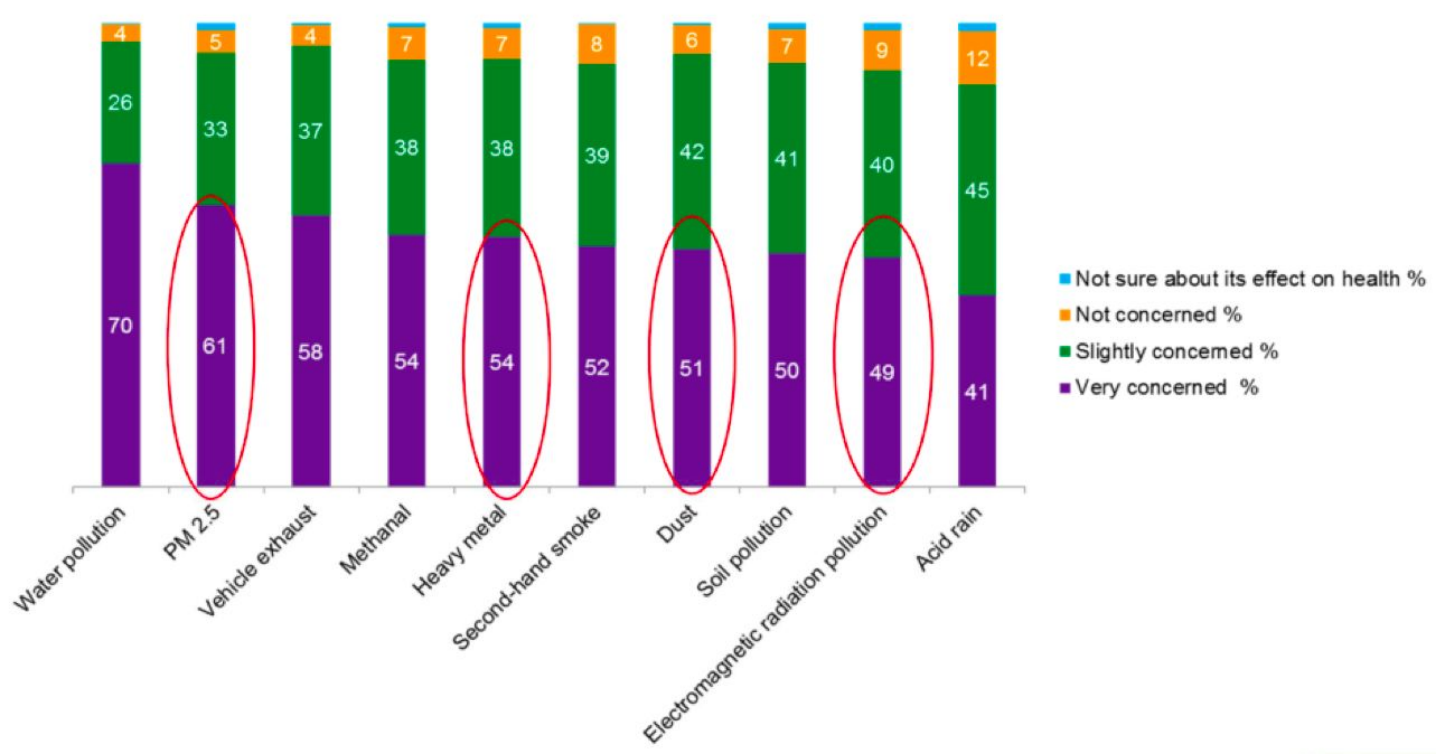

Gambar 1. Jenis Polusi yang Paling Banyak Terjadi Sumber : Mintel, Beauty Around The Clock 2016

Menurut NCBI (National Center for Biotechnology Information di Amerika Serikat), minyak yang berlebih di kulit berkontribusi terhadap pembentukan jerawat. Beberapa permasalahan kulit ini sendiri dapat dijawab dengan produk-produk natural, kulit berjerawat dapat menggunakan face mask dengan kandungan green tea atau tea tree untuk mengurangi peradangan, serta kulit berminyak dapat menggunakan produk berbasis putih telur yang membantu penyerapan produksi minyak berlebih penyebab jerawat. 
Permasalahan-permasalahan kulit wajah ini serta kemajuan teknologi informasi membuat konsumen saat ini mulai mempelajari lebih lanjut produk-produk skin care yang ada terutama produk skin care natural.

\section{TINJAUAN PUSTAKA}

\subsection{Natural Skin Care}

Menurut lembaga sertifikasi kosmetik natural dan organik (termasuk produk skin care) yang diakui secara internasional, NATRUE, kosmetik natural adalah kosmetik yang dibuat dari bahan natural dan telah melewati proses tertentu yang telah ditetapkan NATRUE. Sedangkan bahan baku natural menurut NATRUE adalah bahan yang berasal dari tumbuhan, inorganic-mineral, hewan (kecuali hewan bertulang belakang yang telah mati), dan campuran dari bahan-bahan yang telah disebutkan. Proses pembuatan kosmetik yang diperbolehkan oleh NATRUE adalah proses fisik termasuk ekstraksi, enzymatic, dan reaksi mikrobiologi yang mendekati proses yang terjadi di alam sehingga menghasilkan produk yang mendekati hasil alam.

\subsection{Preferensi Konsumen}

Selera pribadi konsumen yang diukur dari kegunaan dari produk. Preferensi konsumen membuat konsumen dapat mengurutkan kumpulan produk berdasarkan tingkat kegunaan yang diberikan kepada konsumen. Preferensi konsumen tidak dipengaruhi oleh pendapatan dan harga suatu produk karena kemampuan untuk membeli tidak mempengaruhi apa yang disukai atau tidak disukai.

\subsection{Masalah Kulit Wajah}

Masalah kulit wajah merupakan salah satu yang paling sering ditemui. Meskipun rata-rata tidak menyakitkan atau berbahaya, namun masalah kulit wajah seringkali membuat stres karena mudah terlihat, dapat mempengaruhi kepercayaan diri seseorang, dan berakibat pada kualitas hidup yang mengalami permasalahan kulit wajah tersebut. Ada permasalahan kulit wajah yang berbahaya seperti kerusakan kulit 
yang diakibatkan oleh matahari atau kanker kulit yang membutuhkan penanganan klinis segera. Namun di jurnal ini, masalah kulit wajah yang dibahas adalah masalah kulit yang umum dihadapi oleh masyarakat Indonesia.

\subsubsection{Jerawat}

Salah satu permasalahan kulit wajah yang paling banyak ditemui adalah jerawat. Jerawat ini umum ditemukan pada anak remaja dan banyak orang berpikir jerawat sebagai bagian dari proses pertumbuhan. Jerawat ini ternyata tidak hanya disebabkan oleh masa pubertas. Jerawat yang berlebihan ini dapat disebabkan oleh lingkungan hidup yang kurang mendukung (polusi) dan dapat menyebabkan kehilangan rasa kepercayaan diri serta depresi. Saat ini, kasus jerawat juga sudah banyak ditemukan pada orang dewasa berusia 30 hingga 40 tahun. Jerawat juga dapat menyebabkan bekas luka yang mengganggu penampilan sehingga perawatan harus dilakukan secara cepat dan tepat.

\subsubsection{Komedo}

Komedo terbuka atau blackhead adalah benjolan-benjolan kecil pada kulit, yang merupakan pori-pori tersumbat (folikel rambut) yang disebut komedo terbuka. Komedo terjadi apabila kulit memiliki pori-pori terbuka yang tersumbat dengan minyak berlebih, sel kulit mati, dan bakteri. Komedo tampak seperti pori-pori tertutup dengan kotoran, namun merupakan kombinasi minyak dan bakteri yang berubah menjadi hitam saat terpapar dengan udara. Komedo terbuka atau blackheads berbeda dengan komedo tertutup, atau yang dikenal dengan whiteheads. Komedo terbuka adalah gejala umum dari jerawat dan biasanya muncul pada wajah. Terkadang komedo juga dapat muncul pada punggung, leher, lengan atau pundak.

\subsubsection{Kulit Keriput}

Kulit keriput adalah lipatan dan atau garis yang muncul di wajah. Umumnya keriput muncul seiring dengan pertambahan usia namun keriput juga dapat muncul setelah menghabiskan banyak waktu kontak dengan air. Keriput pertama yang terbentuk di wajah seseorang disebabkan oleh ekspresi wajah. Paparan matahari, 
merokok, dehidrasi, pengobatan tertentu, dan kondisi lingkungan tertentu dapat mendorong terbentuknya keriput di wajah. Umumnya keriput cenderung muncul di bagian tubuh yang paling sering terpapar sinar matahari, seperti wajah dan leher, punggung tangan, dan lengan karena sinar ultraviolet merusak kolagen dan serat elastis dalam kulit. Serat ini membentuk jaringan konektif. Mereka terletak di bawah kulit dan bertujuan menyangga kulit. Kerusakan pada jaringan ini membuat kulit menjadi tidak elastis sehingga kendur dan keriput muncul.

\subsubsection{Kulit Kusam}

Kulit kusam adalah kulit yang memiliki tampilan tidak segar dan tidak bercahaya sehingga kulit wajah terlihat sedikit keabu-abuan. Banyak faktor yang menyebabkan kulit terlihat kusam seperti: faktor lingkungan (debu, sinar matahari, dan polusi udara), kesehatan tubuh (stres, kekurangan zat besi), dan kurangnya perawatan kulit (tidak melakukan exfoliating dan kurang minum air).

\section{METODOLOGI PENELITIAN}

Penelitian masker wajah berbahan natural dilakukan menggunakan penelitian eksploratif melalui pendekatan qualitative research. Data collection menggunakan data primer dan data sekunder. Data primer diperoleh melalui direct procedures yaitu, in-depth interview dan Focus Group Discussion (FGD). In-depth interview dilakukan dengan mendatangi narasumber ahli dibidang skin care, produsen skin care dan importir bahan dasar kosmetika. Sedangkan FGD dilakukan untuk mengetahui market insight tentang produk perawatan wajah lebih dalam dari sudut pandang wanita dengan latar belakang yang berbeda. FGD dilakukan 2 kali, tahap yang pertama kepada 6 orang wanita pelajar SMP-SMA dengan usia 15-18 tahun, dan tahap yang kedua kepada 7 orang wanita kuliah-kerja dengan umur 19-30 tahun.

Berdasarkan data dan market insight yang didapat melalui depth interview dan FGD, analisa untuk penelitian diperkuat menggunakan kuesioner tentang masker perawatan wajah kepada 200 responden wanita berumur 15-60, tahun dengan 
mayoritas domisili di pulau Jawa dan sisanya dari seluruh Indonesia. Hasil kuesioner kemudian di analisa secara eksploratif. Sedangkan untuk data sekunder, diperoleh dari internet, literatur, dan jurnal.

\section{ANALISIS DATA}

Berdasarkan hasil masukan tentang masker wajah yang didapat dari Focus Discussion Group yang telah dilakukan, peneliti mendapati bahwa kulit wajah yang sehat adalah kulit wajah yang tidak kering, tidak berjerawat, dan cerah. Selain itu peserta juga memiliki permasalahan kulit wajah yang paling sering dialami yaitu komedo dan jerawat serta kulit berminyak.

Kebanyakan dari peserta juga lebih memilih untuk meracik sendiri produk perawatan kulit wajah, misal : masker wajah dari bahan-bahan natural dan alami. Mereka menggunakan masker wajah tersebut untuk mengeringkan komedo, membuat wajah lebih cerah dan mengangkat sel kulit mati. Selain itu penggunaan masker wajah para peserta dapat dikatakan cukup sering sekitar 2 kali penggunaan dalam seminggu.

Berdasarkan masukan dan pendapat dari para peserta FGD, kami kemudian memproses masukan tersebut menjadi sebuah data kuantitatif yang disebarkan kepada para peserta lain melalui kuesioner yang disebar kepada para wanita di seluruh Indonesia.

\section{Domisili tempat anda tinggal saat ini?}

\section{2 responses}
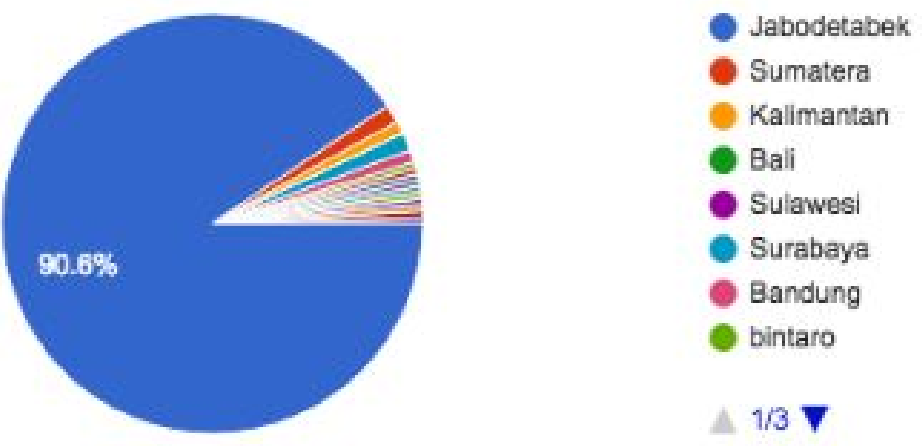

Gambar 2. Domisili pengisi kuesioner 
Menurut hasil kuesioner yang telah dilakukan, Penulis menyebar kuesioner selama 5 hari kepada 200 orang responden wanita, dengan 48,1\% responden berada di rentang usia 20-25 tahun dan 40,6\% berada di rentang usia 26-30 tahun. Kuesioner ini dilakukan guna mendapatkan respon yang lebih spesifik mengenai perilaku konsumen produk masker perawatan wajah. Domisili responden mayoritas berada di Jabodetabek dan pulau Jawa, yaitu sebesar 90,6\%.

Berdasarkan hasil kuesioner yang dilakukan sebagian besar masalah kulit wajah yang paling sering dihadapi adalah jerawat, komedo, kulit berminyak dan kulit kusam. Perawatan wajah dilakukan untuk mengurangi jerawat, komedo, menghilangkan kulit kusam dan mencerahkan wajah. Perawatan wajah untuk kulit kusam berguna untuk skin renewal atau anti aging kulit wajah. Sebesar 55,7\% responden menyatakan sangat setuju untuk mempertimbangkan bahan natural pada produk perawatan kulit. Label natural pada produk perawatan kulit juga menjadi pertimbangan responden dalam membeli produk perawatan kulit. Hal ini diketahui sebanyak $45,8 \%$ responden sangat setuju dengan adanya label "natural" pada produk perawatan kulit.

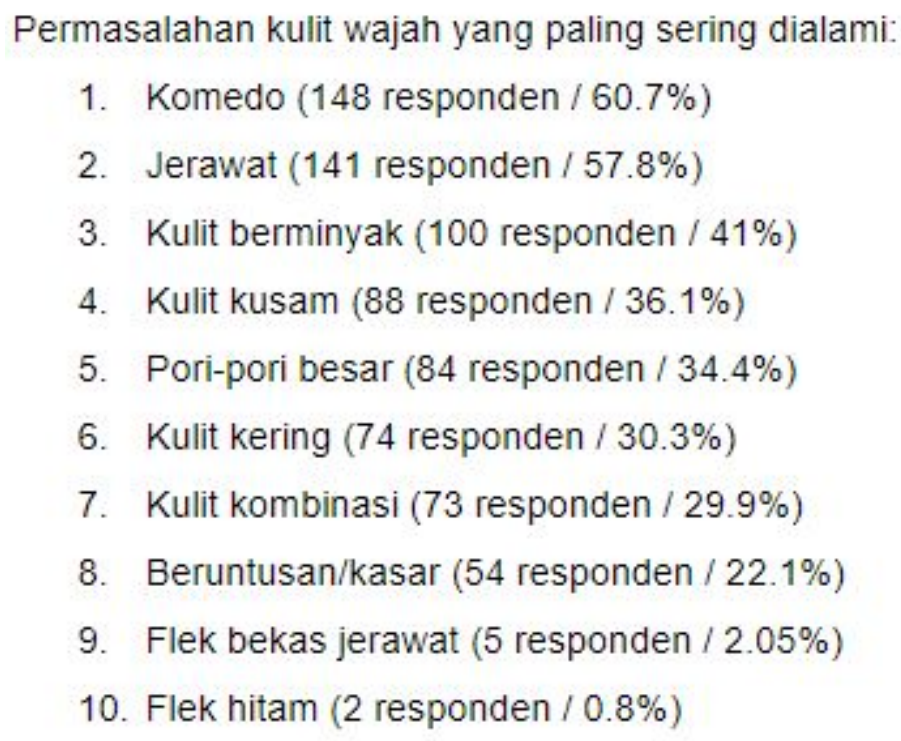


Dari segi intensitas penggunaan, konsumen mayoritas melakukan perawatan menggunakan masker wajah satu kali dalam seminggu, serta beberapa kali dalam seminggu, diikuti dengan beberapa kali dalam sebulan serta satu kali dalam sebulan. Hasil ini menunjukkan bahwa pengguna sudah rutin dalam penggunaan produk masker perawatan wajah.

\section{Seberapa sering anda menggunakan masker perawatan wajah?}
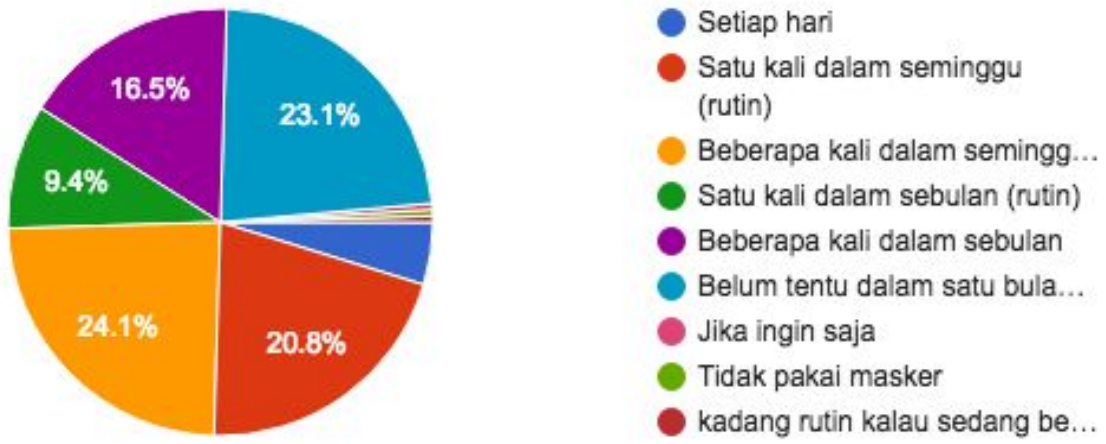

Gambar 4. Intensitas penggunaan produk masker wajah

Sebanyak $87,7 \%$ responden menyatakan bahwa paling sering menggunakan produk perawatan kulit wajah di rumah Hasil dari kuesioner ini memvalidasi FGD yang telah dilakukan bahwa permasalahan kulit wajah yang paling utama adalah jerawat, komedo, dan kulit kusam. Salah satu perawatan wajah yang dilakukan adalah menggunakan skin care berbahan natural.

\section{Saya mempertimbangkan label natural pada produk perawatan wajah.}

\section{2 responses}

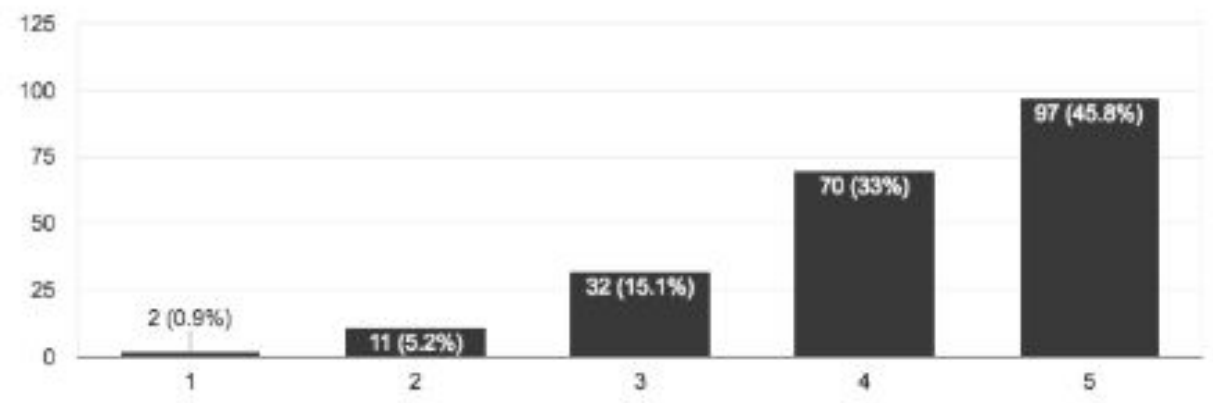

Gambar 5. Preferensi konsumen terhadap produk natural (5: sangat penting) 


\section{KESIMPULAN}

Industri produk perawatan kulit saat ini sendiri terus berkembang dan tren menunjukkan bahwa produk perawatan kulit yang bersifat natural yang banyak diminati oleh konsumen. Banyak perusahaan dan pengusaha yang mengklaim produknya bersifat natural, namun tidak dapat memberikan bukti nyata bahwa produknya benar-benar natural.

Konsumen saat ini juga mulai memilih produk perawatan kulit wajah dengan banyak mempertimbangkan label natural, dan bahan baku natural. Mereka beranggapan produk natural lebih alami untuk mengatasi permasalahan kulit wajah mereka yang disebabkan oleh polusi dan iklim yang terjadi di Indonesia. 


\section{DAFTAR PUSTAKA}

Boston Consulting Group, (2012). “Asia’s Next Big Opportunity: Indonesia’s Rising Middle-class and Affluent Consumers".

Euromonitor International.(2017)."Beauty and Personal Care in Indonesia”. Mei 2017.

Euromonitor International.(2017). "Beauty Survey 2017: Insights and System Update”. Oktober 2017.

Euromonitor International.(2018). "Consumer Lifestyles in Indonesia” . Januari 2018.

Euromonitor International.(2017). “ Consumer Types : Indonesia”. Oktober 2017.

Euromonitor International.(2017). "Global Plastic Tubes : Performance and Opportunity in Beauty and Personal Care”. Agustus 2017.

Fung Global Retail \& Technology.(2017). “ The Face Mask Market is Booming But So Is the Competition”. November 2017.

Kwek, Sharon Si Ling.(2017). "Beauty Opportunities in Southeast Asia" in Seminar Beauty Opportunities in Asia, Hotel Kempinsky Jakarta, 29 Agustus 2017.

Kwek, Sharon Si Ling.(2017)."Beauty Round The Clock" in seminar BeautyOpportunities in Asia, Hotel Kempinsky Jakarta, 29 Agustus 2017

Schagen, Silke. K(2012). "Discovering the Link Between Nutrition and Skin Aging”.PubMed Central. Diakses dari https://www.ncbi.nlm.nih.gov/pmc/articles/PMC3583891/.

Wu, Sarah. (2016, Maret 10). You Can Find The Secret Ingrendient for Clear Skin In Your Morning Breakfast. Diakses Dari https://www.teenvogue.com/story/eggs-korean-skincare-secret.

Asia : Pollution Index 2018, Numbeo, https://www.numbeo.com/pollution/region_rankings.jsp?title=2018-mid\&region=142;

Diakses tanggal : 13 Agustus 2018 


\section{LAMPIRAN}

\section{LAMPIRAN KUESIONER}

Sebanyak 90,6\% atau 192 responden berdomisili di Jabodetabek. Untuk Sumatera, Surabaya, dan Bandung, masing-masing terdapat 3 responden. Kalimantan terdapat 2 responden.

\section{Domisili tempat anda tinggal saat ini?}

\section{2 responses}
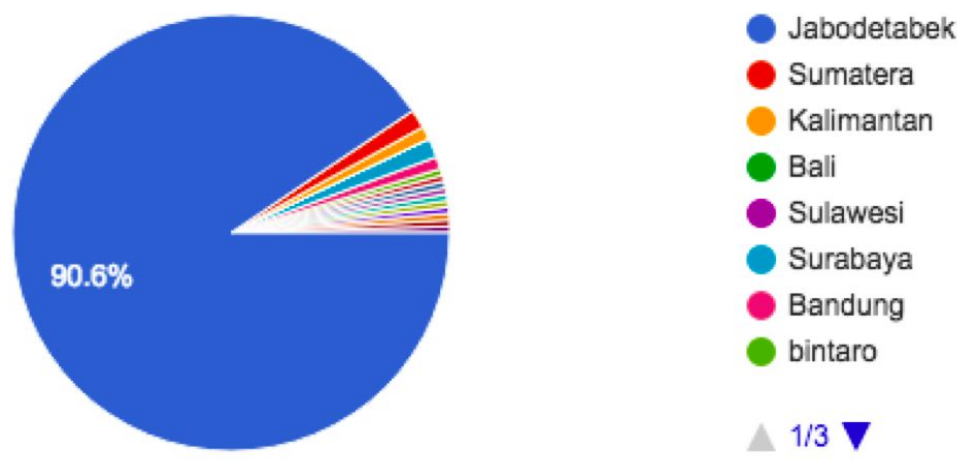

Permasalahan kulit wajah yang paling sering dialami:

1. Komedo (148 responden / 60.7\%)

2. Jerawat (141 responden / 57.8\%)

3. Kulit berminyak (100 responden / 41\%)

4. Kulit kusam (88 responden / 36.1\%)

5. Pori-pori besar (84 responden / 34.4\%)

6. Kulit kering (74 responden / 30.3\%)

7. Kulit kombinasi (73 responden / 29.9\%)

8. Beruntusan/kasar (54 responden / 22.1\%)

9. Flek bekas jerawat (5 responden / 2.05\%)

10.Flek hitam (2 responden / 0.8\%) 
Saya mempertimbangkan produk masker perawatan wajah yang berbahan natural.

212 responses

150

100

$118(55.7 \%)$

50

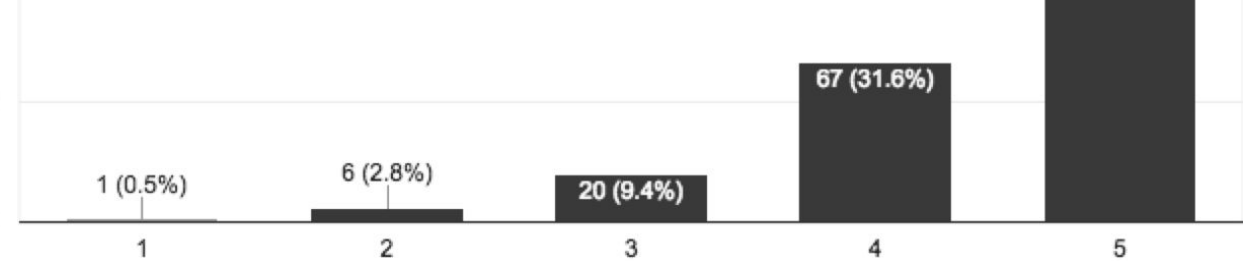

Saya mempertimbangkan label natural pada produk perawatan wajah. 212 responses

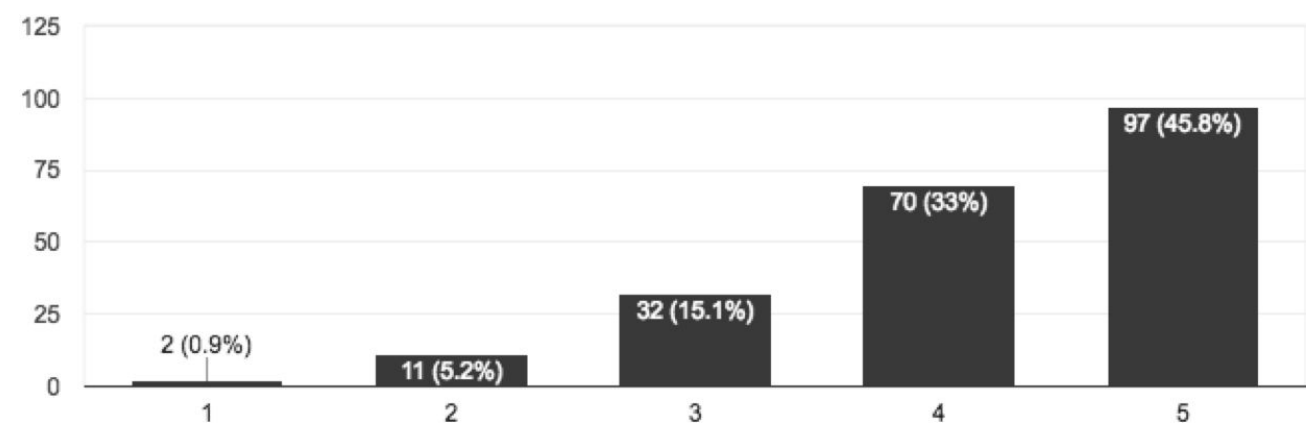

Saya mempertimbangkan label "no animal testing" pada produk masker perawatan wajah.

212 responses

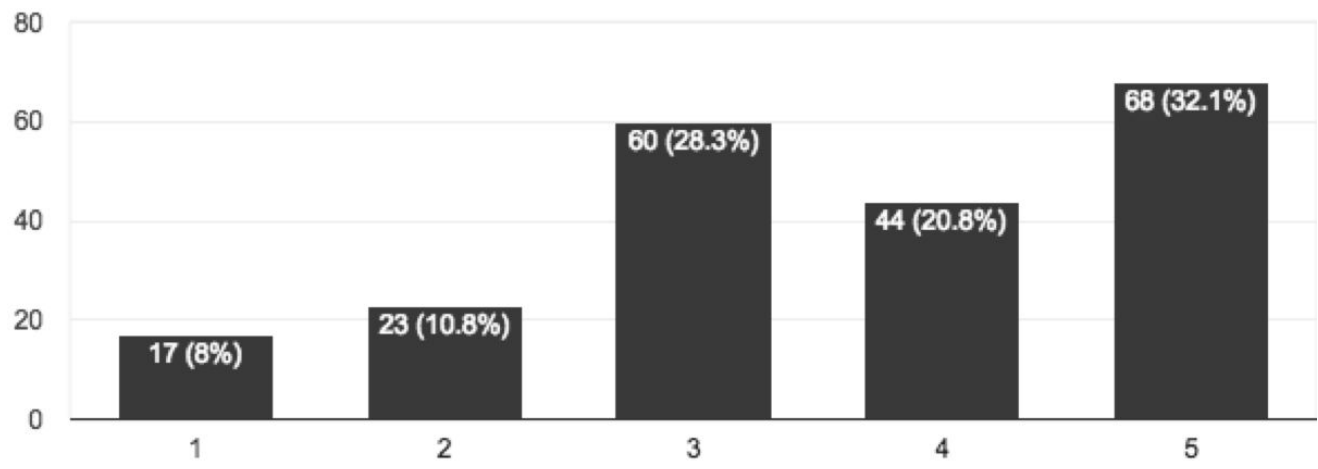

